\title{
MICROBES ASSOCIATED WITH DIRTY SHOES INTERCEPTED AT NEW ZEALAND'S INTERNATIONAL AIRPORTS
}

\author{
S.D. YOUNG, M.R. MCNEILL, E.M. GERARD, \\ C.B. PHILLIPS and M. O'CALLAGHAN \\ AgResearch Ltd, Lincoln Research Centre, Private Bag 4749, Christchurch \\ Corresponding author: sandra.young@agresearch.co.nz
}

Soil on footwear and other items carried by passengers arriving at New Zealand airports from overseas is regarded as a significant biosecurity risk, but many details remain to be clarified. A Better Border Biosecurity (www.b3nz.org) funded study is being conducted to investigate the viability and diversity of micro-organisms present on contaminated footwear. Soil and organic matter adhering to footwear belonging to incoming international passengers was collected from Christchurch International Airport between 08-14 March 2006. Total numbers of culturable bacteria and fungi were enumerated from 34 samples. Culture-independent analysis of the genetic diversity of bacterial communities present in the soil samples was carried out using PCR-DGGE. Bacteria were cultured from all of the samples with a wide range of colony morphologies observed. Selected isolates were identified as typical soil bacteria including Bacillus spp. and Microbacteriaceae. Thirty-two (94\%) of the soil samples also contained culturable fungi. Reasonably high numbers of bacteria and fungi were recovered from all samples, despite many of the soil samples being very dry. All soil samples contained a diverse range of PCR-DGGE ribotypes, with the number of ribotypes per sample averaging 28. The presence of numerous viable micro-organisms in the samples suggests significant biosecurity risks could be present. 